\title{
Peningkatan Kreativitas Mahasiswa Dan Pemuda Dalam Mengembangkan Tanaman Sayuran Hidroponik Organik
}

\author{
Zulzain llahude ${ }^{1}$, Sartin Miolo ${ }^{2}$ \\ ${ }^{1,2}$ Fakultas Pertanian, Universitas Negeri Goontalo Jl. Jend. Sudirman No.6, Dulalowo \\ Tim., Kota Tengah, Kota Gorontalo, Gorontalo 96128, Indonesia \\ Email; zulzainilahude@ung.ac.id ${ }^{1}$, sartin@ung.ac.id ${ }^{2}$
}

\begin{abstract}
Abstrak
Tujuan kegiatan pengabdian pada masyarakat ini adalah 1) mendorong mahasiswa bersama pemuda tani untuk menguasai teknologi pertanian, 2) mengembangkan kreatifitas mahasiswa dalam budidaya sayuran organik dengan inovasi teknologi hidroponik, 3) memanfaatkan limbah organik seperti kotoran hewan, sisa tanaman berupa jerami, serbuk kayu, arang sekam, sebagai media pupuk organik, 4) memberikan praktek langsung cara membuat hidroponik sederhana, menjaga kesuburan tanah bagi tanaman, dan kewirausahaan. Metode berupa praktek aplikasi langsung mengenai pembuatan pupuk organik, budidaya sayuran, dan teknik membuat hidroponik sederhana. Adapun lokasi kegiatannya di Desa Tunggulo, Tungulo Selatan, dan Bongoime Kecamatan Tilong Kabila, Kabupaten Bone Bolango Provinsi Gorontalo. Kegiatan ini diikuti oleh 34 orang mahasiswa KKS Jurusan Agroteknologi dan Jurusan lainnya di Universitas Negeri Gorontalo serta berkolaborasi dengan pemuda tani, dilaksanakan selama 40 hari sejak tanggal 08 September sampai 10 Oktober 2020. Hasil kegiatan menunjukkan bahwa kegiatan pengabdian masyarakat di Desa mitra, terlaksana dengan lancar dan sesuai program yang direncanakan. Mahasiswa dan pemuda tani mengembangkan teknik pembuatan hidroponik dengan komoditas dan media tanam organik yang memanfaatkan kompos kotoran ternak dan arang sekam. terlaksana dengan lancar dan sesuai program yang direncanakan. Mahasiswa dan pemuda tani mengembangkan teknik pembuatan hidroponik dengan komoditas dan media tanam organik yang memanfaatkan kompos kotoran ternak dan arang sekam. terlaksana dengan lancar dan sesuai program yang direncanakan. Mahasiswa dan pemuda tani mengembangkan teknik pembuatan hidroponik dengan komoditas dan media tanam organik yang memanfaatkan kompos kotoran ternak dan arang sekam.

Kata kunci: Kreatifitas mahasiswa mengembangkan petanian organik
\end{abstract}

\begin{abstract}
Absract
The objectives of this community service activity are 1) encouraging students and young farmers to master agricultural technology, 2) developing students' creativity in organic vegetable cultivation with hydroponic technology innovation, 3) utilizing organic waste such as animal manure, crop residues in the form of rice straw, sawdust , husk charcoal, as a medium for organic fertilizer, 4) providing direct practice on how to make simple hydroponics, the importance of maintaining soil fertility for plants, and entrepreneurship. Methods in the forming of direct application practice regarding making organic fertilizers, cultivating vegetables, and techniques for making simple hydroponics. The locations of the activities are in the villages of Tunggulo, Tungulo Selatan, and Bongoime, Tilong Kabila District, Bone Bolango Regency, Gorontalo Province. This activity was attended by 34 students' participants from the Department of Agrotechnology and other departments at State University of Gorontalo and collaborated with young farmers, held for 40 days from September 8 to October 10, 2020. The results of the activity showed that community service activities in partner villages were carried out running well and according to the planned program. Students and young farmers have succeeded in developing hydroponic manufacturing techniques with vegetable commodities and organic growing media that use compost of manure and husk charcoal.
\end{abstract}

Keywords: Students' creativity in developing organic farming 
(C) 2019 Zulzain Ilahude, Sartin Miolo

Under the license CC BY-SA 4.0

Correspondence author: Zulzain Ilahude, zulzainilahude@ung.ac.id, Gorontalo, and Indonesia

\section{PENDAHULUAN}

Pemuda Kreatif, salah satu program Kementerian Pemuda dan olah raga yang meningkatkan daya saing dan kualitas pemuda Indonesia. Potensi kreatifitas pemuda dapat menjadi modal untuk meningkatkan usaha, membangkitkan ekonomi, dan menyejahterakan masyarakat. Kreativititas merupakan proses pemunculan gagasan baru dengan konsep yang sudah ada dan harus terbentuk dalam diri mahasiswa sebagai akademisi intelektual yang berkiprah dalam masyarakat. Pengetahuan dan pengalaman dalam belajar menjadi modal utama dalam melakukan kreativitas bagi mahasiswa yang tentunya melalui arahan dan bimbingan para dosen dalam berbagai bidang ilmu seperti pengembangan sistem pertanian di desa.

Modal utama untuk menjadi mahasiswa yang kreatif dan inovatif adalah pola pikir, mental, serta ketekunan. Setiap orang pasti punya pengalaman, pengalaman yang berharga. Selama ini mahasiswa memiliki peran dalam gerakan perubahan karakter bangsa menuju inovasi maju, dimana sekarang ini mahiswa dituntut untuk menciptakan peluang usaha dalam arti bukan lagi menunggu pekerjaan tetapi dapat menciptakan inovasi sebagai lapangan kerja atau usaha baru yang bermanfaat bagi masyarakat. Mahasiswa adalah calon pemimpin yang memilik pola pikir dewasa dan mampu melihat kepentingan bangsa dan negara.

Seiring dengan perkembangan ilmu pengetahuan dan teknologi, berbagai mahasiswa membutuhkan keterampilan dalam organisasi atau organisasi masalah dan memanfaatkan potensi sumberdaya yang tersedia di daerahnya terutama potensi desa. Wilayah desa merupakan tumpuan pembangunan yang memiliki potensi khusus dalam bidang pertanian. Potensi desa yang lain berupa pemuda sebagai generasi penerus penggerak budidaya pertanian di desa. Pemuda desa inilah dapat menjadi 
mitra mahasiswa untuk mentransfer inovasi teknologi pertanian yang diharapkan dapat dikembangkan secara lebih luas kepada masyarakat.

Desa Bongoime, Tunggulo Selatan, dan Tunggulo, Kecamatan Tilong Kabila Kabupaten Bone Bolango adalah kawasan pertanian yang berada di wilayah terdekat dengan Kampus Universitas Negeri Gorontalo yang dijadikan desa binaan dan patut dikembangkan dalam bidang pertanian. Budidaya komoditas pertanian yang dapat dikembangkan di desa ini antara lain adalah komoditas sayuran yang mudah dan murah perawatannya serta memiliki nilai jual dengan waktu panen yang singkat. Mengkonsumsi sayuran sangat baik bagi kesehatan tubuh manusia. Belakangan ini berkembangnya teknologi banyak metode yang digunakan dalam penanaman sayuran.

Teknologi hidroponik yang akan digunakan dalam kegiatan ini adalah penggunaan pupuk organik dengan pola tanam menggunakan bahan yang mudah, murah, sederhana dan tersedia. Penggunaan bahan organik berupa pupuk kompos ini membuat sayuran lebih tahan lama dan bebas dari bahan kimia yang berbahaya, bahkan sayuran organik memiliki rasa yang renyah. Inovasi teknologi ini dapat mengasah kreatifitas mahasiswa, mengasah menulis, menyampaikan serta menerapkan ide, memperoleh pengalaman, pengakuan dan mendapat kenalan atau koneksi, dan yang paling besar manfaatnya adalah membantu pembangunan desa yang maju dan mandiri dalam pemenuhan pangan. Sebagai wujud implementasi program Kampus Merdeka atau belajar merdeka, maka pada program proyek di desa ini akan diikuti oleh mahasiswa dari berbagai jurusan, Hal ini dilakukan untuk memberikan kebebasan kepada mahasiswa untuk melakukan inovasi dan kreativitasnya di desa khususnya dalam bidang pertanian. Mengingat bahwa pertanian menjadi tumpuan utama pembangunan perdesaan, maka patut menjadi motivator dan pendorong pembangunan pembangunan perdesaan.

Pada kegiatan Pengabdian Pada Masyarakat kegiatan ini telah dilaksanakan pada tiga desa dengan kolaborasi masyarakat pemuda 
menjadi desa binaan dalam mengembangkan desa dengan pemenuhan pangan dan berbasis organik.

Tujuan kegiatan pengabdian pada masyarakat ini adalah: 1) mendorong mahasiswa untuk menguasai bidang pertanian yang berguna bagi pemuda tani milenial, 2) mengembangkan kreatifitas mahasiswa dalam budidaya sayuran organik dengan inovasi teknologi hidroponik sederhana, 3) memanfaatkan limbah organik seperti kotoran hewan, sisa tanaman berupa jerami padi, serbuk kayu, arang sekam, sebagai media pupuk organik, 4) memberikan praktek aplikasi tentang cara membuat hidroponik sederhana, menjaga kesuburan tanah bagi tanaman, dan kewirausahaan. Manfaat kegiatan ini untuk meningkatkan inovasi dan peran mahasiswa dalam bidang pertanian bagi petani milenial di desa.

Target kegiatan ini adalah: 1) terciptanya kepedulian dan empati mahasiswa kepada permasalahan masyarakat yang berada di desa tunggulo selatan kabupaten tulang bolango, sehingga terjadi perubahan prilaku mahasiswa dan masyarakat khususnya pemuda atau petani milenial dalam menyikapi pentingnya penerapan budidaya tanaman sayuran untuk menanggulangi pangan dan gizi masyarakat, 2) terciptanya pengetahuan mahasiswa dan pemuda tani untuk memproduksi sayur dengan membuat media tanam pupuk organik dengan teknologi hidroponik sederhana. hal ini dilakukan untuk mengatasi permasalahan kelangkaan produksi sayur yang ada di desa maupun daerah sekitarnya,

\section{METODE PELAKSANAAN}

Pelaksanaan Kegiatan KKS Universitas Negeri Gorontalo, meliputi tahapan persiapan seperti: Survei Lokasi Desa mitra, Pembekalan (coaching) mahasiswa dan Dosen Pembimbing Lapangan (DPL), Koordinasi dengan pihak mitra, Persiapan perlengkapan, Penerimaan Mahasiswa oleh Pemerintah Desa / Kecamatan, Penyusunan rencana program. 
Pelaksanaan kegiatan KKS bagi mahasiswa Universitas Negeri Gorontalo Program Merdeka Belajar Tahun 2020, diawali dengan pembekalan. Adapun materi pembekalan meliputi:

a. Sebuah. Peran Universitas Negeri Gorontalo dalam peningkatan kualitas sumberdaya manusia

b. Aktualisasi kebijakan akademik dalam pelaksanaan KKS Universitas Negeri Gorontalo

c. Falsafah (arti, tujuan, sasaran dan manfaat dari KKS

d. Rencana program dan pengorganisasian KKS

e. Peran KKS dalam meningkatkan IPM dan MDGs

f. Etika pergaulan, bersosialisasi dan mendekati partisipasi masyarakat

g. Peran komunikasi dalam pelaksanaan program di lokasi KKS

h. Latihan penyusunan rencana program dan pengorganisasian KKS

i. Deskripsi tugas, tata tertib, pelaporan, dan produksi mahasiswa KKS

Pelaksanaan kegiatan pembekalan mahasiswa telah diikuti oleh 34 orang, terdiri dari mahasiswa jurusan Agribisnis, Agroteknologi, dan Teknologi Pengolahan Pangan Fakultas Pertanian universitas Negeri Gorontalo. Selanjutnya persiapan perlengkapan dan atribut bawaan oleh panitia LPPM Universitas Negeri Gorontalo sesuai dengan rencana. Program KKS Pengabdian Universitas Negeri Gorontalo tahun 2020 dengan tema "Peningkatan Kreativitas Mahasiswa dan Pemuda Dalam Mengembangkan Tanaman Sayuran Organik dengan Sistem Hidroponik" telah dilaksanakan dengan mengutamakan prinsip pemberdayaan masyarakat khususnya petani milenial. Program ini dilaksanakan terintegrasi dengan program pemuda dan masyarakat tani dan dilaksanakan secara langsung melalui bimbingan dan arahan DPL dan aparat desa mitra.

1. Arahan dan bimbingan oleh DPL tentang penyusunan program kerja bersama aparat desa mitra, mengamati situasi potensi desa. Efektifitas dan efisiensi program yang tak terkalahkan dengan 
waktu dan sumber daya yang ada merupakan hal penting dalam peencanaan program kerja KKS.

2. Ada tiga program yang dilaksanakan pada kegiatan KKS ini yaitu; Program utama sesuai dengan tema yaitu pengembangan kreatifitas mahasiswa dan pemuda tani dalam mengembangkan tanaman sayuran organik dengan media hidroponik. Ada program yang tak terkalahkan dengan kondisi desa, serta program tambahan lainnya.

3. Pelaksanaan program utama telah diikuti oleh seluruh peserta KKS di tiga desa dengan mengikusertakan pemuda tani dan aparat desa. Hasil kegiatan berupa pembuatan media hidroponik yang berskala rumah tangga dengan ornamen yang bervariasi sesuai arsitektur yang disepakati. Kegiatan lainnya yang serupa adalah pembuatan media vertikultur untuk tanaman sayuran di Desa Tunggulo selatan. Model ini sempat menarik perhatian masyarakat. Sebagai media tanam digunakan bahan organik kompos yang telah difermentasi selama dua minggu dan digunakan untuk tanaman sayuran. Pada pembuatan kompos ini student to teladan ditengah para pemuda tani dan masyarakat lainnya. Penanaman aneka tanaman obat-obatan juga merupakan program yang menggunakan media kompos organik.

4. Program tambahan seperti pembuatan tempat sampah di rumah penduduk dan bakti sosial juga mewarnai kegiatan KKS di desa mitra.

5. Kegiatan pemantauan dan evaluasi oleh DPL dilakukan melalui kunjungan langsung ke lokasi tiga desa mitra, dengan menyertakan aparat desa dan pemuda tani.

6. Evaluasi program dilakukan dengan membandingka sebelum dan sesudah pelaksanaan program pengabdian KKS di desa mitra. 
Program Kuliah Kerja Sibermas (KKS) - Pengabdian bertema "Peningkatan Kreativitas Mahasiswa dan Pemuda Dalam Mengembangkan Tanaman Sayuran Organik dengan Sistem Hidroponik. Sebagai desa mitra ada tiga, yaitu: Desa Bongoime, Tunggulo dan Tunggulo Selatan, Kecamatan Tilong Kabila, Kabupaten Bonebolango, Provinsi Gorontalo "yang bersinergi dengan masyarakat lokal, maka diharapkan permasalahan - permasalahan yang muncul di lapangan dapat diatasi. Program ini menitikberatkan pada konsep pemberdayaan masyarakat, dimana masyarakat dijadikan sebagai pelaku utama dan pihak perguruan tinggi yang berperan sebagai pendamping. Melalui program ini diharapkan bahwa tujuan dari program KKS - Pengabdian dapat dicapai dengan meningkatkan kreativitas dan potensi di Desa mitra bidang pertanian dan pemenuhan pangan berkelanjutan.

Secara khusus program ini memiliki beberapa tujuan adalah 1) mendorong mahasiswa bersama pemuda tani untuk menguasai teknologi pertanian, 2) mengembangkan kreatifitas mahasiswa dalam budidaya sayuran organik dengan inovasi teknologi hidroponik sederhana, 3) memanfaatkan limbah organik seperti kotoran hewan, sisa tanaman berupa jerami padi, serbuk kayu, arang sekam, sebagai media pupuk organik, 4) memberikan aplikasi praktek langsung tentang cara membuat hidroponik sederhana dengan memanfaatkan barang bekas, menjaga kesuburan tanah bagi tanaman, dan kewirausahaan. Hal ini akan bermuara pada kesadaran dan kesadaran masyarakat, keberdayaan masyarakat, dan kesejahteraan masyarakat.

\section{HASIL DAN PEMBAHASAN}

Kecamatan Tilongkabila terdiri dari 14 Desa. Luas Kecamatan Tilongkabila secara keseluruha adalah $79.74 \mathrm{~km} 2$. Desa terluas di Kecamatan Tilongkabila adalah Lonuo dengan presentase 23 dan desa yang memiliki luas terkecil adalah Desa Berlian dengan presentase 0.65 Permukaan tanah di Kecamatan Tilongkabila sebagian besar adalah dataran rendah dan pengunungan. Secara Geografis dan secara administratif Desa Bongoime merupakan salah satu dari 14 
Desa di Kecamatan Tilongkabila Kabupaten Bone Bolango, dan memiliki luas wilayah $\pm 228,3 \mathrm{Ha}$ secara topografis terletak pada ketinggian 100 meter diatas permukaan laut. Posisi Desa Bongoime yang terletak pada bagian Barat Kabupaten Bone Bolango berbatasan langsung dengan sebelah barat Desa Toto Utara - Desa Berlian dan Desa Motilango, sebelah timur Desa Tunggulo Selatan dan Desa Bongohulawa, sebelah utara Desa Tamboo dan sebelah selatan Desa Poowo dan Desa Poowo Barat.

Sedangkan Tunggulo merupakan salah satu dari 14 desa diwilayah kecamatan Tilongkabila yang terletak $1 \mathrm{~km}$ kea rah Timur dari kecamatan Tilongkabila. Desa tunggulo mempunyai luas wilayah seluas $\pm 1.829,27 \mathrm{H}$. Iklim Desa Tunggulo, sebagaimana desa-desa lain diwilayah Indonesia mempunyai iklim kemarau, penghujan dan pancaroba. Hal tersebut mempunyai pengaruh langsung terhadap pola tanam dan keadaan masyarakat di Desa Tunggulo Kecamatan Tilongkabila.

Produksi tanaman hortikultura paling banyak di Kecamatan Tilong kabila, dimana Produksi Cabai 2016-2018 (BPS 2019) sebanyak 27 Ton, 34 Ton, dan 74.9 Ton.Terjadi peningkatan hasil produksi Cabai pada tahun 2018 dibanding dengan tahun 2017 sebesar 40.9 Ton , sedangkan kelapa terjadi penurunan hasil produksi Kelapa pada tahun 2018 dibanding dengan tahun 2017 sebesar 147.91 Ton.

Implementasi beberapa program dan kegiatan yang telah dilaksanakan melalui kegiatan pengabdian pada masyarakat di tiga desa mitra berjalan lancar sesuai dengan rencana dan program kerja. Kegiatan tersebut berupa peningkatan kreativitas mahasiswa, masyarakat dan pemuda tani dalam mengembangkan pertanian organik dengan pola tanam menggunakan berbagai media tanam seperti aquaponik dan bahan kompos organik. Hasil karya mahasiswa berupa aquaponik yang digabungkan dengan komoditas sayuran dan ikan yang telah dikembangkan bersama pemuda tani seperti pada Gambar di bawah ini. 


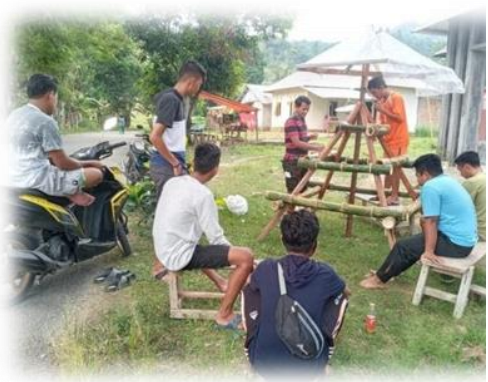

Gambar 1a

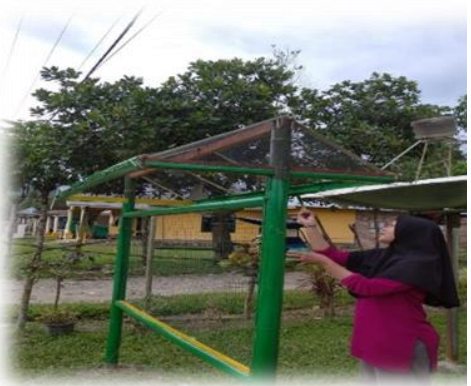

Gambar 1b

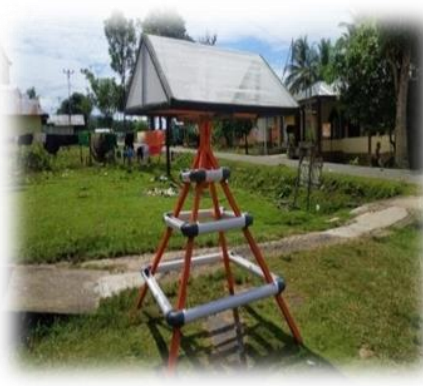

Gambar 1c

Gambar 1a, 1b, 1c Merancang model hidroponik bersama pemuda

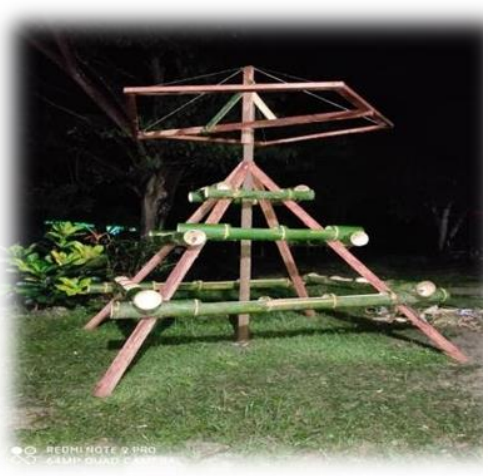

Gambar 2a

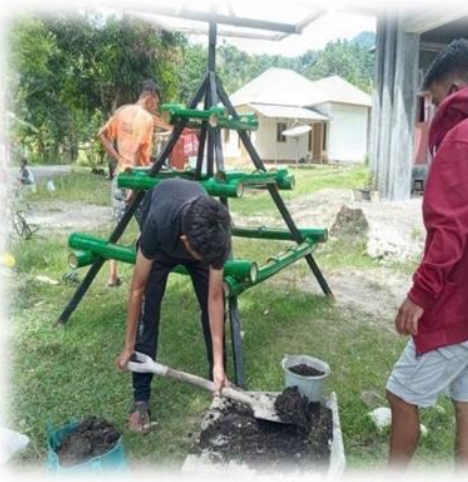

Gambar 2b

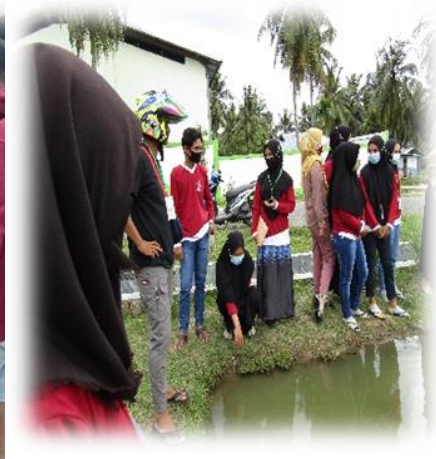

Gambar 2c

Gambar 2a, 2b, 2c Kegiatan mendesain hidroponik organik

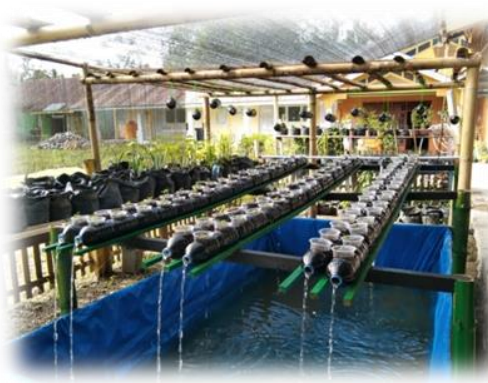

Gambar 3a

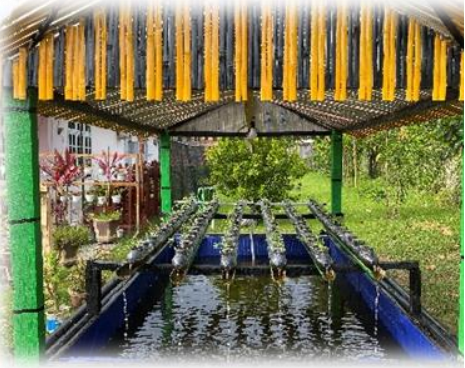

Gambar 3b

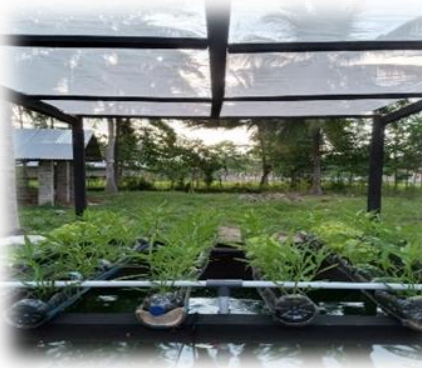

Gambar 3c

Gambar 3a, 3b, 3c Hidroponik / aquaponik siap digunakan

Kegiatan lainnya yang telah berhasil dilakukan bersama masyarakat ibu rumah tangga seperti pembuatan media tanam untuk tanaman obatobatan TOGA (Tanaman Obat Keluarga) dngan menggunakan media arang sekam sebagai kompos organik. Demikian pula penananam tanaman bunga yang sudah langka ditemukan yaitu bunga pukul sepuluh 
sebagai penciri tanaman lokal yang dipelihara sejak puluhan tahun yang lalu dan berfungsi sebagai penarik serangga hama pengganngu juga sebagai pemanis halaman rumah. Penanaman bunga pukul 10 ini memanfaatkan ban bekas dan media kompos kotoran ternak yang difermentasi. Beberapa kegiatan tersebut seperti tertera dalam gambar di berikut ini.

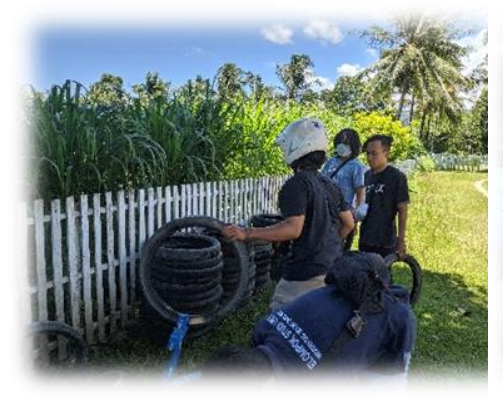

Gambar 4a

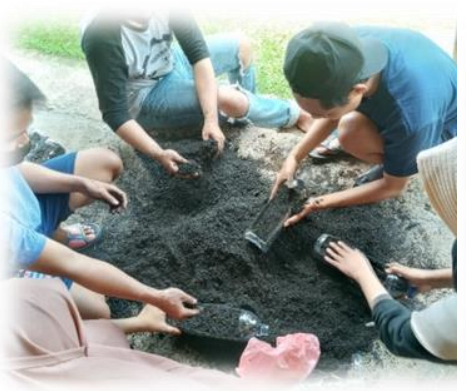

Gambar 4b

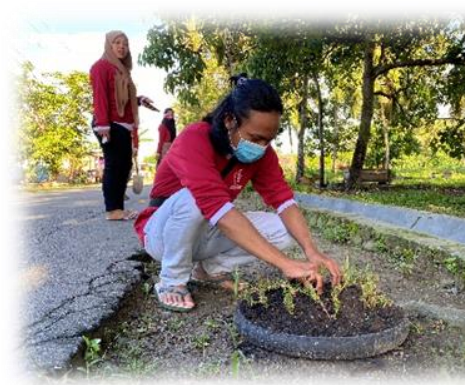

Gambar 4c

Gambar 4a, 4b, Pembuatan media tanam organik untuk tanaman $4 \mathrm{c}$ pekarangan

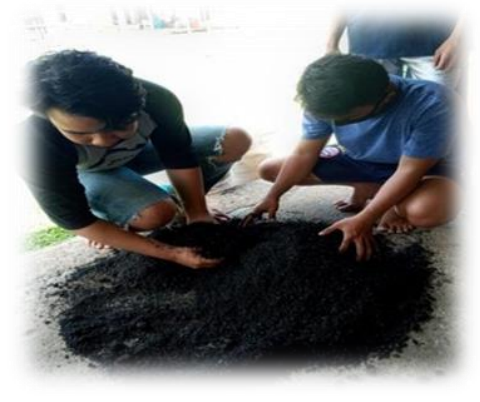

Gambar 5a

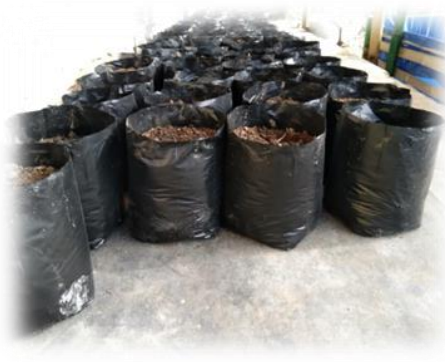

Gambar 5b

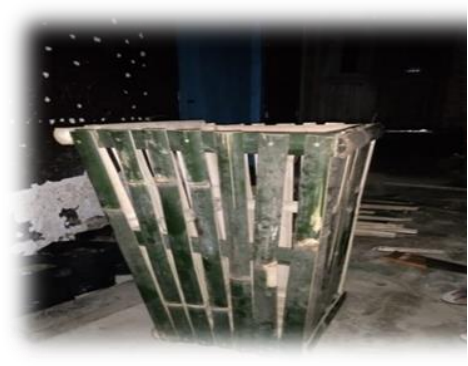

Gambar 5c

Gambar 5a

Pupuk kompos dan arang sekam

Gambar 5b

Media polybag untuk tanaman obat-obatan toga

Gambar 5c

Tempat sampah sederhana dan praktis

Selain kegiatan fisik juga banyak kegiatan sosial seperti membantu aparat desa dalam kegiatan sosialisasi program kemasyarakatan dan kegiatan olah raga kesenian untuk memotivasi kaum mudadalam mengembangkan bakan dan minatnya. 
Selama kegiatan berlangsung dilakukan pengawasan dan pemantauan secara rutin oleh DPL dan aparat Desa mitra dengan maksud agar kegiatan terarah dan dapat berlangsung lancar.

Program pemantauan dan evaluasi Pelaksanaan KKS terselenggara dengan baik dengan adanya Koordinator desa (Kordes) di desa mitra dan Koordinator kecamatan (Korcam) yang melakukan kegiatan selama berlangsungnya KKS. Berikut kegiatan monitoring dan evaluasi di desa mitra bersama mahasiswa dan aparat desa mitra.

Setelah dilakukan evaluasi secara keseluruhan program berjalan dengan lancar masih terdapat atau hambatan teknis dapat diatasi bersama. Kelengkapan teknis yang dihadapai seperti kurangnya sosialisasi mahasiswa ke seluruh lingkungan desa lokasi KKS, sehingga ruang lingkup kegiatan masih terbatas pada lokasi tertentu. Disamping itu pula pemahaman yang bervariasi KKS Kampus Merdeka karena belum ada akademik baru yang mengikat sebagai acuan aturan di UNG Gorontalo.

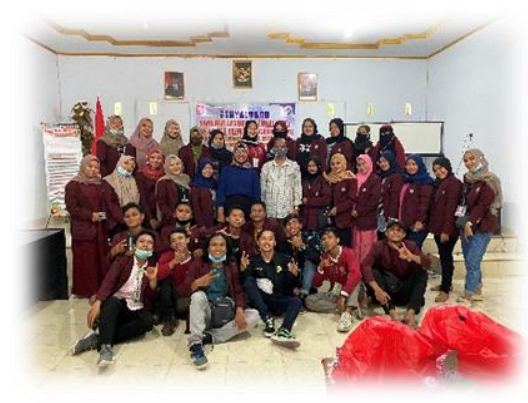

Gambar 6a

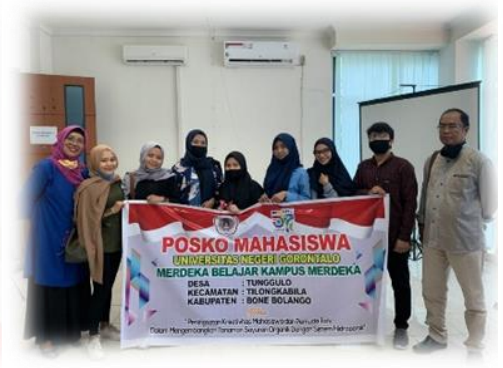

Gambar 6b

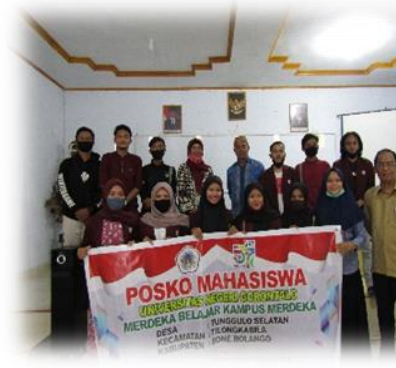

Gambar 6c

Gambar 6a, 6b, 6c Monitoring dan evaluasi program kerja 


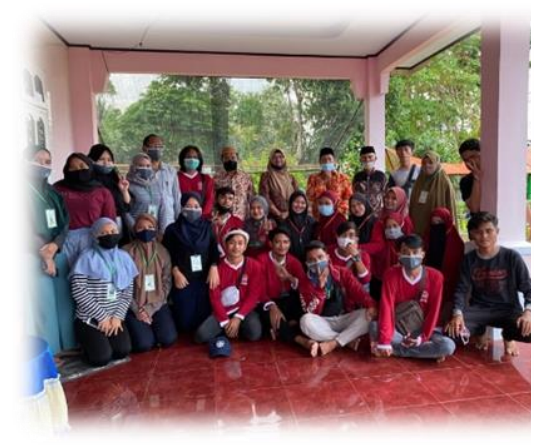

Gambar 7a

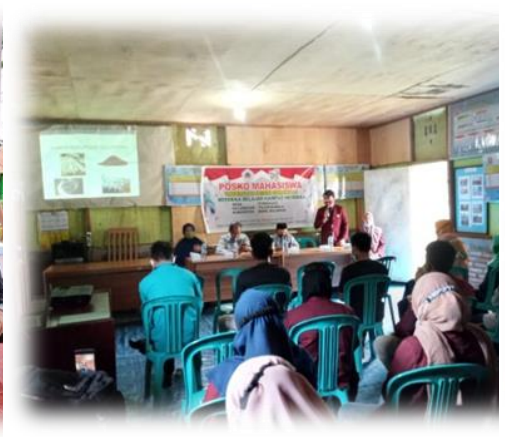

Gambar 7b

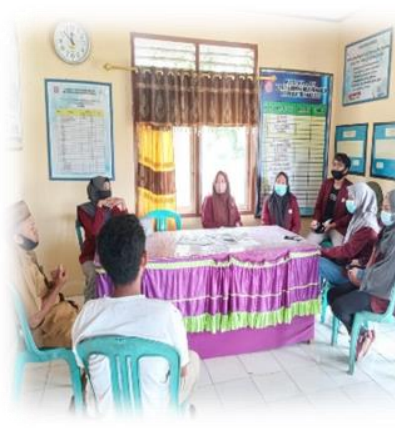

Gambar 7c

Gambar 7a, 7b, 7c Silaturahmi dan keakraban dengan aparat desa

Walau terdapat namun mahasiswa KKS menunjukkan bukti berkiprah di tengah masyarakat perdesaan dalam melakukan berbagai kegiatan dan telah menunjukkan kreatifitas serta inovasi teknologi sederhana yang dapat diterima oleh masyarakat sesuai dengan kondisi dan potensi desa mitra.

\section{KESIMPULAN}

Pelaksanaan KKS dengan tema "Peningkatan Kreativitas Mahasiswa dan Pemuda Tani Dalam Mengembangkan Tanaman Sayuran Organik dengan Sistem Hidroponik" telah berhasil dilaksanakan dengan mengutamakan prinsip pemberdayaan masyarakat, petani milenial bersama mahasiswa dibawah bimbingan dan koordinasi DPL dan apparat desa mitra.

Program lainnya yang terealisasi seperti penggunaan pekarangan rumah dengan menanam berbagai sayuran, tanaman obat-obatan dan bunga-bungaan yang menggunakan barang bekas dn media tanam organik berupa kotoran ternak yang telah difermentasi dan arang sekam yang bermanfaat bagi kesuburan tanah. Tanggapan dan antusiasme masyarakat serta pemuda desa terhadap keberadaan program KKS di desa sangat membantu kepentingan pembangunan perdesaan.

Sebaiknya desa mitra yang cocok dengan Kampus Bonebolango ini dijadikan sebagai desa binaan dalam mengembangkan pertanian secara 
berkelanjutan melalui kegiatan belajar mengajar, penelitian dan pengabdian masyarakat.

Pentingnya membangun sinergitas antara pihak pimpinan Kampus Universitas Negeri Gorontalo dengan Pemerintah daerah Pemda Kabupaten Bonebolango dalam pembangunan pertanian yang berkelanjutan.

\section{UCAPAN TERIMA KASIH}

Penulis mengucapkan banyak terimakasih kepada Tim atas waktunya. Turut serta ucapan terima kasih penulis sampaikan kepada rekan-rekan sejawat yang menjadi teman diskusi sehingga menyempurnakan pengabdian ini.

\section{REFERENCES}

Anonim, 2020. Kerangka Acuan Kegiatan (KAK) Merdeka Belajar Kampus Merdeka. Lembaga Penelitian dan Pengabdian Kepada Masyarakat Universitas Negeri Gorontalo.

Anang, 2017. Hidroponik Sebagai Sarana Pemanfaatan Lahan sempit di Dusun Bangunharjo Sleman Bantul. Jurnal Pemberdayaan Vol. 1 oktober 2017.

BPS, 2019. Kecamatan Tilongkabila dalam angka. Badan Pusat Statistik Kabupaten Bone Bolango.

Roidah, 2013. Manfaat Penggunaan Pupuk Organik Bagi Kesuburan Tanah. Jurnal Universitas Tulung Agung BONOROWO vol 1 No.1 Tahun 2013

llahude, Z., Miolo.S. 2020. Laporan KKS tahun 2020 https://youtu.be/aJcNwt6rmpM 